\title{
Penerapan Engaged Learning Strategy Dalam Menumbuhkembangkan Tanggung Jawab Belajar dan Kemampuan Koneksi Matematis Siswa Sekolah Menengah Atas
}

\author{
Libri Kartika $\mathrm{S}^{1)}$ Edy Tandililing $\mathrm{S}^{2)}$ Bistari $\mathrm{S}^{3)}$ \\ 1) Prodi Pascasarjana Pendidikan Matematika FKIP UNTAN, Pontianak, Indonesia \\ E-mail:librikartikasarari@yahoo.com
}

\begin{abstract}
Abstrak. Penelitian ini bertujuan untuk mengungkap tanggungjawab belajar dan kemampuan koneksi matematis siswa pada materi Fungsi Logaritma di kelas X IPA SMA Negeri 3 Singkawang yang menerapkan Engaged Learning Strategy. Dalam penelitian ini yang dimaksud dengan tanggung jawab belajar adalah sikap dan perilaku siswa yang menunjukkan kepatuhan umum dengan standar perilaku yang diharapkan serta komitmen sehubungan dengan belajar akademik siswa, yang bisa dilihat dari aspek-aspek seperti: (1) Memiliki Inisiatif, Otonomi dan Kendali Belajar (2) Berpartisipasi Aktif dalam Pembelajaran, (3) Orientasi Positif terhadap Sekolah, (4) Mampu Memanajemen Sumber Belajar. Sedangkan kemampuan koneksi matematis adalah kemampuan siswa menemukan dan menggunakan keterkaitan antar konsep dalam matematika dan kemampuan siswa menemukan dan menggunakan keterkaitan konsep matematika dengan masalah dalam kehidupan sehari-hari. Metode penelitian yang digunakan adalah Quasi Experiment (Eksperimen Semu) dengan rancangan one-group pre-test post-test design, dimana kemampuan koneksi matematis 37 siswa dalam pembelajaran diukur sebelum dan setelah pembelajaran yang menerapkan Engaged Learning Strategy. Dalam penelitian ini, tanggung jawab belajar diukur dengan menggunakan kuesioner penilaian diri sedangkan kemampuan koneksi matematis siswa diukur dengan menggunakan tes uraian. Hasil penilaian diri kemudian diolah dengan skala Likert yang dikonversi menjadi data kuantitatif sementara hasil tes uraian diolah dengan mengacu pada pedoman penskoran. Hasil analisis data menunjukkan secara umum tanggung jawab belajar siswa meningkat sebesar $6 \%$ dimana peningkatan terbesar adalah indikator Berpartisipasi Aktif dalam pembelajaran. Hal ini terjadi karena masalah nyata yang digunakan dalam pembelajaran sehingga dapat memotivasi siswa untuk menginvestasikan minatnya dalam belajar. Sedangkan untuk kemampuan koneksi matematis dibatasi dalam penelitian ini hanya untuk koneksi dengan kehidupan sehari-hari dan antar konsep matematika. Secara keseluruhan kemampuan koneksi matematis mengalami peningkatan skor rata-rata sebesar $1,5 \%$.
\end{abstract}

Kata Kunci: Engaged Learning Strategy, Tanggung Jawab Belajar, Koneksi Matematis

\section{PENDAHULUAN}

Koneksi matematis merupakan satu di antara kemampuan yang menjadi tujuan pembelajaran matematika yang dimuat dalam kurikulum 2006 dan juga tersirat dalam kurikulum 2013. Kemampuan koneksi matematis adalah kemampuan mengaitkan konsep-konsep matematika baik antar konsep matematika maupun mengaitkan konsep matematika dengan bidang lainnya (luar matematika). Kemampuan koneksi matematis diperlukan siswa karena matematika merupakan satu kesatuan, di mana konsep yang satu berhubungan dengan konsep yang lain. Demikian pentingnya kemampuan koneksi matematis, National Council Teacher Mathematics [1] dalam buku Prinsip dan Standar Matematika Sekolah menyatakan bahwa saat siswa dapat menghubungkan ide-ide matematika, maka pemahaman mereka akan lebih dalam dan bertahan lama.

Namun fakta di lapangan menunjukkan bahwa kemampuan koneksi matematis siswa di Indonesia masih rendah. Hal ini dapat dilihat di dunia internasional untuk beberapa periode menunjukkan bahwa kemampuan matematika siswa Indonesia berada di ranking bawah. Siswa Indonesia masih dominan dalam level rendah, atau lebih pada kemampuan menghafal dalam pembelajaran sains dan matematika. Hal ini ditunjukkan oleh hasil dari Program for International Student Assessment (PISA) pada tahun 2012 yang menunjukkan kecakapan matematis siswa Indonesia berada pada posisi 64 dari 65 negara. Sementara itu menurut hasil Trends in Mathematics and Science Study (TIMSS) 


\section{A - - Jurnal Pendidikan Matematika Indonesia \\ Volum 1 Nomor 2 bulan September 2016. Halaman 57-64 \\ p-ISSN: 2477-5967 e-ISSN: 2477-8443}

pada tahun 2011 untuk bidang Matematika, Indonesia berada di urutan ke-38 dengan skor 386 dari 42 negara yang siswanya dites. Hal ini disebabkan karena menurut [2], siswa Indonesia tidak mampu menyelesaikan pertanyaan yang membutuhkan pemahaman dan kemampuan berfikir tingkat tinggi. Dari hal tersebut dapat disimpulkan bahwa pemahaman siswa yang tidak baik maka dapat dipastikan bahwa kemampuan koneksi matematis siswa juga tidak baik.

Menurut [3], rendahnya prestasi matematika dapat disebabkan oleh 2 faktor yaitu faktor intern dan faktor ekstern. Satu di antara faktor intern yaitu rendahnya motivasi siswa ketika belajar matematika, sementara faktor ekstern adalah metode dan gaya mengajar guru dalam mengajar mata pelajaran matematika yang dominan dengan gaya "textbook oriented" dan gaya mengajar yang "statis [4]. Peran guru masih sangat dominan (teacher centered), dan gaya mengajar cenderung bersifat satu arah, sehingga tidak terjadi keterlibatan siswa. Akhirnya, proses pembelajaran yang terjadi hanya sebatas pada penyampaian informasi saja (transfer of knowledge), kurang terkait dengan lingkungan sehingga siswa tidak mampu memahami untuk apa belajar matematika dan tidak mampu menghubungkan matematika dengan kehidupan sehari-hari. Pembelajaran yang terjadi menurut Zulkardi [5] terkesan seolah-olah mengakibatkan lepasnya anak tersebut dari lingkungannya, mereka belajar sesuatu yang sama sekali tidak ada hubungannya dengan lingkungan hidupnya.

Tantangan yang dihadapi kebanyakan guru dalam kelas, seperti kurangnya motivasi, siswa yang tidak tertarik pada materi, gangguan sosial dan perilaku dapat diatasi dengan membuat upaya untuk melibatkan siswa dalam proses pembelajaran. Strategi pembelajaran yang melibatkan siswa mengarah pada pengembangan kebiasaan dan kualitas pada siswa yang akan menyebabkan mereka menghargai belajar dan menjadi pebelajar seumur hidup yang memiliki otonomi. Karena itulah peneliti berinisiatif untuk menerapkan Engaged Learning Strategy dalam upaya untuk melibatkan siswa dalam pembelajaran pada materi Fungsi Logaritma di Kelas X IPA.
Engaged learning diwacanakan oleh North Central Regional Educational Laboratory (NCREL) di US. Untuk mencapai tujuan, pebelajar diberikan masalah nyata untuk dipecahkan dalam konteks membangun pengetahuan. Guru berperan sebagai Pembimbing dan Fasilitator untuk mendukung pencapaian pengetahuan dan pengalaman pebelajar. Dalam Engaged Learning peserta didik mengambil tanggung jawab lebih untuk menetapkan tujuan dan mengidentifikasi sumber daya untuk belajar mereka. Sehingga diharapkan strategi ini dapat menumbuhkan tanggung jawab belajar siswa dan selanjutnya mengembangkan kemampuan koneksi matematisnya.

\section{METODE}

Penelitian ini merupakan penelitian Quasi Experiment dengan rancangan one-group pre-test post-test design, dimana kemampuan koneksi matematis 37 siswa sebagai subjek penelitian diukur sebelum dan setelah diberikan Engaged Learning. Pola one group pretest-posttest design ditunjukkan pada tabel berikut ini.

TABEL I

DESAIN PENELITIAN ONE GRoup PRETEST-POSTTEST DESIGN

\begin{tabular}{llll}
\hline Subjek & $\begin{array}{l}\text { Pre- } \\
\text { test }\end{array}$ & Perlakuan & $\begin{array}{l}\text { Post- } \\
\text { test }\end{array}$ \\
\hline $\mathrm{S}$ & $\mathrm{O} 1$ & $\mathrm{X}$ & $\mathrm{O} 2$ \\
\hline
\end{tabular}

Tabel tersebut menjelaskan bahwa kelas dikenakan pretest (O1) untuk mengukur tanggung jawab belajar dan kemampuan koneksi matematis sebelum diberi perlakuan berupa Engaged Learning, kemudian setelah itu diberi post-test (O2).

Dalam penelitian ini siswa diberi 3 perlakuan utama yaitu (1) masalah dunia nyata multidisiplin, (2) konteks membangun pengetahuan dan (3) peran guru sebagai pembimbing dan fasilitator.

Penilaian aktivitas kelas dilakukan oleh Pengamat untuk mengetahui sejauh mana terjadi keterlibatan siswa dalam pembelajaran kemudian dianalisis secara deskriptif dan berdasarkan taraf keberhasilan pelaksanaan indikator (persentase).

Untuk mengetahui bagaimana tanggung jawab belajar yang dimiliki siswa, penulis menggunakan instrumen dengan 32 pernyataan yang mengukur kesesuaian pernyataan dengan tanggung jawab 
belajar yang dimiliki siswa. Untuk analisis tanggung jawab belajar digunakan skala Likert, dimana siswa sebagai responden menentukan tingkat persetujuan mereka terhadap suatu pernyataan dengan memilih salah satu dari pilihan yang tersedia. Dalam penelitian ini disediakan lima pilihan skala, yaitu SS = Sangat Sesuai, $\mathrm{S}=$ Sesuai, TS = Cukup Sesuai, KS = Kurang Sesuai dan STS = Sangat Tidak Sesuai.

Tes kemampuan koneksi matematis untuk pretest merupakan soal uraian pada materi Fungsi Eksponen yang diberikan sejumlah 4 soal, sedangkan untuk post-test merupakan soal uraian pada materi Fungsi Logaritma dengan jumlah 5 soal. Selanjutnya untuk pemberian skor setiap butir soal dilakukan dengan mengikuti pedoman penskoran.

\section{HASIL DAN PEMBAHASAN}

HASIL

Berdasarkan data hasil angket tanggung jawab belajar siswa, maka perbedaan tanggung jawab belajar siswa Kelas XIPA2 SMAN 3 Singkawang sebelum dan setelah mengalami pembelajaran Strategi Engaged Learning disajikan pada tabel berikut.

TABEL 2

PerbedaAn TangGung Jawab Belajar Siswa Sebelum dan SETElah MENGAlami PEMBELAJARAN DENGAN STRATEGI ENGAGED LEARNING

\begin{tabular}{|c|c|c|c|c|c|c|c|}
\hline \multirow[b]{2}{*}{$\begin{array}{l}\mathbf{N} \\
\mathbf{0}\end{array}$} & \multirow[b]{2}{*}{ Indikator } & \multicolumn{3}{|c|}{ Sebelum } & \multicolumn{3}{|c|}{ Sesudah } \\
\hline & & Skor & $\%$ & $\begin{array}{l}\text { Kateg } \\
\text { ori }\end{array}$ & Skor & $\%$ & $\begin{array}{l}\text { Kateg } \\
\text { ori }\end{array}$ \\
\hline 1 & $\begin{array}{l}\text { Memiliki } \\
\text { Inisiatif, } \\
\text { Otonomi } \\
\text { dan } \\
\text { kendali } \\
\text { belajar }\end{array}$ & 121,2 & 58,7 & $\begin{array}{l}\text { Sedan } \\
\mathrm{g}\end{array}$ & 125,0 & 67,6 & $\begin{array}{l}\text { Sedan } \\
\mathrm{g}\end{array}$ \\
\hline 2 & $\begin{array}{l}\text { Berpartisi } \\
\text { pasi Aktif } \\
\text { dalam } \\
\text { Kegiatan } \\
\text { Pembelaja } \\
\text { ran }\end{array}$ & 116,3 & 54,1 & $\begin{array}{l}\text { Sedan } \\
\mathrm{g}\end{array}$ & 126,0 & 67,8 & $\begin{array}{l}\text { Sedan } \\
\mathrm{g}\end{array}$ \\
\hline 3 & $\begin{array}{l}\text { Memiliki } \\
\text { Orientasi } \\
\text { Positif } \\
\text { terhadap } \\
\text { Sekolah } \\
\text { dan } \\
\text { Belajar }\end{array}$ & 113,3 & 61,0 & $\begin{array}{l}\text { Sedan } \\
\mathrm{g}\end{array}$ & 114,0 & 60,8 & $\begin{array}{l}\text { Sedan } \\
\mathrm{g}\end{array}$ \\
\hline 4 & $\begin{array}{l}\text { Manajeme } \\
\text { n Sumber } \\
\text { Belajar }\end{array}$ & 128,5 & 69,5 & Tinggi & 130,0 & 70,3 & Tinggi \\
\hline
\end{tabular}

\begin{tabular}{lllllll}
\hline Rata-rata & $\begin{array}{l}119,8 \\
4\end{array}$ & 60,8 & $\begin{array}{l}\text { Sedan } \\
\mathrm{g}\end{array}$ & 124,0 & 66,8 & $\begin{array}{l}\text { Sedan } \\
\mathrm{g}\end{array}$ \\
\hline
\end{tabular}

Terlihat ecara umum tanggung jawab belajar sebelum mengalami pembelajaran dengan Strategi Engaged Learning adalah $60,8 \%$ sedangkan setelahnya adalah 66,8\%. Peningkatan terbesar terjadi pada indikator Berpartisipasi Aktif dalam Kegiatan Pembelajaran yaitu dari 54,1\% menjadi $67,8 \%$ dan pada indikator Memiliki Orientasi Positif terhadap Sekolah dan Belajar mengalami penurunan dari $61 \%$ menjadi $60,8 \%$.

Selain tanggung jawab belajar penelitian ini juga mengkaji kemampuan koneksi matematis siswa sebelum dan setelah mengalami pembelajaran dengan Strategi Engaged Learning. Perbedaan skor pre-test dan post-test kemampuan koneksi matematis siswa dapat dilihat pada Tabel 3 berikut.

TABEL 3

REKAPITUlasi Hasil PRE-TEST DAN POST TEST KEMAMPUAN KONEKSI MATEMATIS

\begin{tabular}{|c|c|c|c|c|c|c|c|c|c|c|}
\hline \multirow[b]{2}{*}{$\begin{array}{l}\text { Aspek } \\
\text { Koneksi }\end{array}$} & \multirow[b]{2}{*}{$\begin{array}{l}\text { Sko } \\
\mathbf{r} \\
\text { Ma } \\
\text { ks }\end{array}$} & \multicolumn{4}{|c|}{ Pre Test } & \multirow[b]{2}{*}{$\begin{array}{l}\text { Sko } \\
\text { r } \\
\text { Ma } \\
\text { ks }\end{array}$} & \multicolumn{4}{|c|}{ Post Test } \\
\hline & & $\begin{array}{l}\mathbf{x} \\
\mathbf{m i} \\
\mathbf{n}\end{array}$ & $\begin{array}{l}\text { xma } \\
\text { ks }\end{array}$ & $\bar{x}$ & $\begin{array}{l}\text { STD } \\
\text { EV }\end{array}$ & & $\begin{array}{l}\mathbf{x} \\
\mathbf{m i} \\
\mathbf{n}\end{array}$ & $\begin{array}{l}\mathbf{x} \\
\mathbf{m} \\
\text { ak } \\
\mathbf{s}\end{array}$ & $\bar{x}$ & $\begin{array}{l}\text { S } \\
\text { T } \\
\text { D } \\
\text { E } \\
\text { V }\end{array}$ \\
\hline
\end{tabular}

\begin{tabular}{|c|c|c|c|c|c|c|c|c|c|c|}
\hline $\begin{array}{l}\text { Antar } \\
\text { konsep } \\
\text { dalam } \\
\text { matemat } \\
\text { ika }\end{array}$ & 100 & $\begin{array}{c}27 \\
, 3\end{array}$ & 100 & $\begin{array}{r}63 \\
, 4\end{array}$ & 22,0 & 100 & $\begin{array}{c}16 \\
, 7\end{array}$ & $\begin{array}{c}10 \\
0\end{array}$ & $\begin{array}{l}6 \\
5 \\
6 \\
1\end{array}$ & $\begin{array}{l}2 \\
0 \\
3\end{array}$ \\
\hline $\begin{array}{l}\text { Antara } \\
\text { konsep } \\
\text { matemat } \\
\text { ika } \\
\text { dengan } \\
\text { kehidup } \\
\text { an } \\
\text { sehari- } \\
\text { hari }\end{array}$ & 100 & $\begin{array}{r}28 \\
, 6\end{array}$ & 100 & $\begin{array}{r}75 \\
, 5\end{array}$ & 21,1 & 100 & $\begin{array}{c}23 \\
, 1\end{array}$ & $\begin{array}{c}10 \\
0\end{array}$ & $\begin{array}{l}7 \\
6 \\
7 \\
7\end{array}$ & $\begin{array}{l}2 \\
0 \\
\text {, } \\
5\end{array}$ \\
\hline $\begin{array}{l}\text { Rata- } \\
\text { rata }\end{array}$ & 100 & & & $\begin{array}{r}69 \\
, 4\end{array}$ & 18,8 & 100 & & & $\begin{array}{l}7 \\
0 \\
9 \\
9\end{array}$ & $\begin{array}{l}2 \\
0 \\
\text {, } \\
4\end{array}$ \\
\hline
\end{tabular}

Dari Tabel 3 terlihat bahwa skor rerata kemampuan koneksi pada post test lebih tinggi dari pre-test yaitu sebesar 1,5\%. Skor rerata Mengkoneksikan antar konsep dalam matematika pada post test lebih tinggi dari pre-test yaitu sebesar $1,7 \%$. Sejalan dengan itu, skor rerata Mengkoneksikan antara konsep matematika 
dengan kehidupan sehari-hari pada post-test lebih tinggi dari pre-test yaitu sebesar $1,2 \%$.

Selain itu, untuk mengamati keterlaksanaan Strategi Engaged Learning di dalam kelas pada Pembelajaran materi Fungsi Logaritma maka digunakan Lembar Observasi. Yang dinilai oleh pengamat adalah persentase kemunculan mulai dari tidak ada sama sekali hingga sangat jelas $(0-$ $100 \%$ ) yang disertai dengan deskripsi dari indikator tersebut. Semakin tinggi indikatornya semakin tinggi pula keterlibatan siswa yang dicapai. Gambaran secara umum pengamatan terhadap pembelajaran matematika dengan Strategi Engaged Learning dapat dilihat pada Tabel 4 berikut.

TABEL 4

PEMBELAJARAN FungSI LOGARITMA DENGAN STRATEGI ENGAGED LEARNING

\begin{tabular}{|c|c|c|c|c|c|}
\hline \multirow[t]{2}{*}{ Variabel } & \multirow[t]{2}{*}{$\begin{array}{l}\text { Indikator } \\
\text { Engaged } \\
\text { Learning }\end{array}$} & \multicolumn{3}{|c|}{$\begin{array}{l}\text { Persentase } \\
\text { Kemunculan } \\
\text { pada RPP } \\
\text { ke- }\end{array}$} & \multirow[t]{2}{*}{$\begin{array}{l}\text { Deskripsi dari } \\
\text { Pengamat }\end{array}$} \\
\hline & & 1 & 2 & 3 & \\
\hline \multirow[t]{2}{*}{ Kegiatan } & $\begin{array}{l}\text { Masalah } \\
\text { Nyata }\end{array}$ & 95 & 95 & 95 & 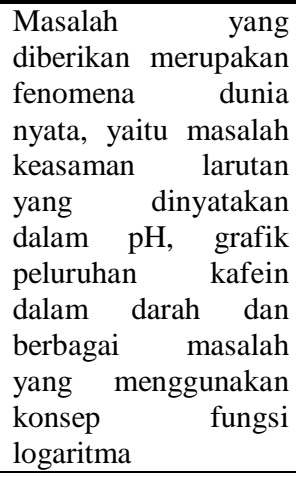 \\
\hline & $\begin{array}{l}\text { Multidisip } \\
\text { lin }\end{array}$ & $\begin{array}{c}10 \\
0\end{array}$ & $\begin{array}{c}10 \\
0\end{array}$ & $\begin{array}{c}10 \\
0\end{array}$ & $\begin{array}{l}\text { Kegiatan } \\
\text { pembelajaran } \\
\text { melibatkan masalah } \\
\text { dalam bidang kimia } \\
\text { (perhitungan } \mathrm{pH} \text {, } \\
\text { geografi (besaran } \\
\text { gempa) dan fisika } \\
\text { (intensitas suara) }\end{array}$ \\
\hline $\begin{array}{l}\text { Model } \\
\text { Pembelaja } \\
\text { ran }\end{array}$ & Interaktif & 90 & 90 & 90 & $\begin{array}{l}\text { Pembelajaran } \\
\text { dirancang sedemikian } \\
\text { sehingga komunikasi } \\
\text { terjadi dua arah } \\
\text { antara guru-siswa dan } \\
\text { siswa-siswa }\end{array}$ \\
\hline $\begin{array}{l}\text { Konteks } \\
\text { Belajar }\end{array}$ & $\begin{array}{l}\text { Membang } \\
\text { un- } \\
\text { pengetahu } \\
\text { an }\end{array}$ & 70 & 80 & 75 & $\begin{array}{l}\text { Untuk mencari nilai } \\
\text { logaritma dengan } \\
\text { basis tertentu, siswa } \\
\text { tidak bisa langsung } \\
\text { melakukannya } \\
\text { dengan kalkulator, } \\
\text { dan akhirnya siswa } \\
\text { menggunakan sifat }\end{array}$ \\
\hline
\end{tabular}

\begin{tabular}{|c|c|c|c|c|c|}
\hline & & & & & $\log _{a} b=\frac{\log b}{\log a}$ \\
\hline $\begin{array}{l}\text { Pengelom- } \\
\text { pokan }\end{array}$ & Heterogen & $\begin{array}{c}10 \\
0\end{array}$ & $\begin{array}{c}10 \\
0\end{array}$ & $\begin{array}{c}10 \\
0\end{array}$ & $\begin{array}{l}\text { Kelompok dibuat } \\
\text { heterogen tanpa } \\
\text { melihat kemampuan, } \\
\text { jenis kelamin suku } \\
\text { maupun agama }\end{array}$ \\
\hline \multirow[t]{2}{*}{$\begin{array}{l}\text { Peran } \\
\text { Guru }\end{array}$} & Fasilitator & 80 & 90 & 85 & $\begin{array}{l}\text { Guru menyediakan } \\
\text { lingkungan yang kaya } \\
\text { sumber belajar } \\
\text { (menyarankan kata } \\
\text { kunci untuk } \\
\text { pencarian internet } \\
\text { dan menyiapkan } \\
\text { beberapa buku untuk } \\
\text { dipinjam siswa) dan } \\
\text { beragam pengalaman } \\
\text { belajar (memberikan } \\
\text { kesem-patan untuk } \\
\text { mencermati berbagai } \\
\text { konsentrasi rion } \\
\text { hidrogen dengan nilai } \\
\text { pH-nya) }\end{array}$ \\
\hline & $\begin{array}{l}\text { Pembimbi } \\
\text { ng }\end{array}$ & 80 & 90 & 85 & $\begin{array}{l}\text { Guru membimbing } \\
\text { siswa dengan } \\
\text { skaffolding saat siswa } \\
\text { bertanya. }\end{array}$ \\
\hline \multirow[t]{2}{*}{$\begin{array}{l}\text { Peran } \\
\text { Siswa }\end{array}$} & Eksplorer & 85 & 80 & 85 & $\begin{array}{l}\text { Siswa bereksplorasi } \\
\text { menggunakan } \\
\text { software kalkulator } \\
\text { saintific melalui hp } \\
\text { android mereka (My } \\
\text { Script, Math Type, } \\
\text { Google) }\end{array}$ \\
\hline & Guru & 85 & 75 & 85 & $\begin{array}{lr}\text { Siswa mengajari } \\
\text { siswa yang lain yang } \\
\text { sekelompok dengan } \\
\text { mereka }\end{array}$ \\
\hline
\end{tabular}

Dari tabel diatas, kehadiran indikator pengelompokan mencapai $100 \%$ karena pengelompokan untuk tiap RPP diatur secara heterogen tanpa melihat kemampuan, jenis kelamin, suku ataupun agama. Kemudian disusul oleh kegiatan belajar yang mengangkat masalah nyata dan multidisiplin dengan skor 97,5\%. Peran guru sebagai pembimbing dan fasilitator mencapai skor $85 \%$, sementara untuk indikator Pembelajaran Interaktif mencapai skor 90\%, dilanjutkan Konteks pembelajaran Membangun Pengetahuan sebesar 75\%, dan yang terakhir Peran siswa sebagai Eksplorer dan Guru bagi rekan yang lain adalah sebesar $82,5 \%$. Setelah dirata-rata ternyata keterlibatan siswa dalam pembelajaran menurut Pengamat adalah $88,3 \%$.

Pengamat secara kualitatif juga mencatat dua hal untuk keterlibatan Afektif yaitu (1) Siswa tetap fokus pada kegiatan pembelajarannya, fokus 


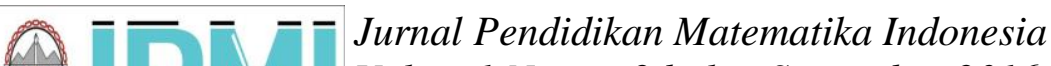 \\ Volum 1 Nomor 2 bulan September 2016. Halaman 57-64 \\ p-ISSN: 2477-5967 e-ISSN: 2477-8443}

dalam menggunakan kalkulator untuk menampilkan hasil penyajian $\mathrm{pH}$ dari konsentrasi ion Hidrogen dan (2) Tidak tampak ada siswa yang menampilkan emosi negatif; nampak sangat bosan, banyak menguap, kepala tertelungkup di atas meja.

Sedangkan untuk keterlibatan Perilaku, Pengamat mencatat beberapa hal berikut (1) Siswa berusaha untuk menentukan nilai $\mathrm{pH}$ suatu substansi ternyata kalkulator tidak langsung menyiapkan fungsi logaritma yang bisa langsung dipakai sehingga mereka harus menggunakan sifat logaritma yaitu $\log _{a} b=\frac{\log b}{\log a} \quad$, (2) Meskipun memegang alat komunikasi namun perhatian siswa tidak teralihkan oleh sesuatu yang tidak berhubungan dengan tugas, (3) Guru tidak harus mengingatkan siswa untuk terus menyelesaikan tugasnya dan (4) Siswa aktif bertanya baik dengan sesama rekan maupun dengan guru.

\section{PEMBAHASAN}

Tujuan dari Engaged Learning adalah untuk menghasilkan peserta didik yang memiliki tanggung jawab belajar, strategik dalam mengelola pembelajaran mereka sendiri, antusias dalam mengejar pemahaman; dan kolaboratif dalam pengaturan sosial. Siswa yang memiliki tanggung jawab belajar dicirikan dengan 4 indikator yaitu (1) Memiliki inisiatif, otonomi dan kendali belajar (2) Berpartisipasi Aktif dalam Pembelajaran, (3) Memiliki Orientasi Positif terhadap Sekolah, (4) Manajemen Sumber Belajar.

Dari hasil angket setelah pembelajaran dengan Strategi Engaged Learning untuk indikator ke-2 yaitu Berpartisipasi Aktif dalam Pembelajaran terjadi peningkatan paling besar yaitu dari $54,1 \%$ menjadi $67,8 \%$ atau sebesar $13,8 \%$. Hal ini didukung oleh peningkatan indikator Inisiatif, Otonomi dan Kendali Pribadi yang erat kaitannya dengan motivasi. Pada awal pembelajaran matematika dengan strategi Engaged Learning, siswa masih bingung dalam menentukan tujuan belajarnya. Mereka belum pernah menentukan tujuan belajarnya sendiri. Biasanya, guru lah yang menginformasikan tujuan pembelajaran untuk hari tersebut. Dalam meminta siswa untuk merumuskan tujuan mereka, guru ikut berperan agar siswa lebih terarah dalam merumuskannya dengan menopang siswa lewat apersepsi. Sebelumnya guru mengajukan masalah derajat keasaman suatu substansi yang biasanya dinyatakan dalam $\mathrm{pH}$. Dari masalah tersebut siswa dimintai memberi tanggapan berupa pertanyaan. Lima dari tujuh kelompok yang ada secara garis besar menanyakan hal yang sama "Bagaimana hubungan antara konsentrasi ion hidrogen dengan $\mathrm{pH}$ ?”. Dengan rumusan pertanyaan dari siswa tersebut, guru mengarahkan bahwa tujuan belajar mereka hari ini adalah untuk mengetahui bagaimana fungsi logaritma membantu ilmuan dalam menyajikan informasi konsentrasi ion hidrogen yang dinyatakan dalam fungsi logaritma. Dengan menyadari tujuan belajarnya, akan membuat siswa strategik dalam mencapai tujuannya tersebut. Selain itu juga proses menetapkan tujuan dapat meningkatkan belajar dan motivasi siswa, khususnya saat siswa menetapkan tujuan mereka sendiri, mereka mengambil tanggung jawab dan kepemilikan dari tujuan belajar mereka seperti yang disampaikan oleh [6].

Selain itu peningkatan partisipasi siswa juga didukung oleh hadirnya masalah nyata dan pembelajaran interaktif yang merupakan indikator dari Engaged Learning Strategy. Menurut siswa masalah-masalah yang diajukan dapat mereka bayangkan sehingga mereka dapat menggunakan pemikiran mereka untuk menyesuaikan dengan informasi baru yang mereka dapatkan dalam pembelajaran. Ini menyebabkan mereka tetap fokus dalam pembelajaran. Ini sejalan dengan pendapat NCREL bahwa masalah nyata dapat membawa siswa untuk terlibat dalam pembelajaran.

Sementara itu Indikator ke-3 mendapatkan sumbangan yang besar dari deskriptor Adanya keinginan dan kemauan yang kuat untuk menekuni belajar yang meningkat $12,7 \%$ dari $58,4 \%$ menjadi $71,1 \%$. Melalui diskusi dengan siswa terungkap bahwa mereka baru dapat melihat bahwa sebenarnya matematika memiliki manfaat dalam kehidupan nyata. Selain itu, pemberian masalah di awal pembelajaran menjadikan tantangan bagi siswa untuk memecahkan masalah tersebut sehingga dapat memicu pertanyaan-pertanyaan, 
membuat konjektur, dan memunculkan gagasan serta pendapat yang beranekaragam. Hal ini sejalan dengan pendapat Lampert [7] yang mengungkapkan bahwa alasan yang paling penting untuk memilih suatu masalah atau tugas adalah seyogyanya masalah dapat melibatkan semua siswa di kelas dalam membuat dan menguji hipotesis matematika.

Dalam menyelesaikan LKS mereka, hampir semua kelompok pada awalnya mengalami masalah. Disinilah peran guru sebagai pembimbing dibutuhkan. Siswa diminta untuk menyajikan derajat keasaman beberapa substansi yang diketahui konsentrasi ion Hidrogennya. Jumlah konsentrasi ion Hidrogen ini sangat kecil, namun bukan hal tersebut yang menjadi masalah. Meskipun di LKS sudah diinformasikan bahwa nilai ph dari substansi sama dengan $-\log \left[\mathrm{H}^{+}\right]$, namun begitu masuk perhitungannya siswa mengalami masalah. Misalnya untuk jus jeruk yang memiliki konsentrasi ion hidrogen 0.00501187233627 , maka nilai $\mathrm{pH}$ nya adalah $\log [0.00501187233627]$. Ternyata siswa tidak mengerti bagaimana menggunakan kalkulator dalam menyelesaikannya. Dalam hal ini guru sebagai pembimbing tidak langsung memberikan jawaban bagaimana menyelesaikannya, namun memberikan siswa topangan sebagai berikut :

Guru : Berapa nilai $\log _{10} 100$ ?

Siswa : (sambil bergumam kecil '10 dipangkatkan berapa jadi 100') 2

Guru : Ya. Sifat-sifat logaritma apa saja yang kalian ingat?

Siswa : (Siswa menyebutkan beberapa sifat logaritma) $\log _{\alpha} b=\frac{\log b}{\log a}$

Guru : Ya, yang itu. Jika $\log _{a} b=\frac{\log b}{\log \alpha}$, maka $\log _{10} 100$ bagaimana?

Siswa : $\log _{10} 100=\frac{\log 100}{\log 10}$. (Siswa lalu mencoba memencet kalkultornya dengan cara pembagian logaritma dengan basis 10). $\mathrm{O}$ Iya bu, benar. Hasilnya 2. Jadi jika $-\log [0.0050118723362]=$ $-\frac{\log [00050118723362]}{10}$

ya bu?

Hal ini tampaknya sering luput dari perhatian guru matematika, karena peneliti mencoba mengkonfirmasi kepada rekan sesama guru matematika bagaimana cara mereka menentukan nilai suatu logaritma. Ternyata jawabannya adalah tabel, bukan kalkulator. Menurut penulis penggunaan kalkulator untuk materi logaritma bukanlah sesuatu yang akan membawa keburukan. Karena siswa juga perlu merasakan bahwa logaritma juga merupakan sebuah angka. Dan untuk sebagian besar penggunaan logaritma dalam kehidupan nyata maka penggunaan kalkulator mutlak diperlukan, contohnya untuk kasus diatas tadi. Disinilah guru berperan sebagai rekan belajar bagi siswa, karena selama ini guru hanya berkutat dengan masalah-masalah logaritma yang jauh dari bayangan siswa.

Yang patut diperhatikan adalah turunnya indikator Orientasi Positif Terhadap Sekolah sebesar $0,2 \%$ yang merupakan sumbangan dari deskriptor Menghormati Aturan yang Dibuat sekolah yang turun sebesar $12,4 \%$. Hal ini dapat dipahami bahwa Tanggung Jawab Belajar untuk deskriptor ini lebih cenderung ke arah kepatuhan bukan komitmen. Sehingga pengaruh dari luar (Sekolah) sangat mempengaruhi deskriptor ini. Menurut [8] perencanaan program kedisiplinan siswa perlu melibatkan seluruh stake holder sekolah sehingga kendala-kendala yang ada dalam pelaksanaan dapat diatasi dengan efektif. Kurang koordinasi dalam melaksanakan peraturan sekolah menurut penulis merupakan salah satu sebab turunnya deskriptor Menghormati Aturan yang Dibuat sekolah. Semakin banyaknya pelanggaran peraturan sekolah yang tidak direspon tegas oleh sekolah, menyebabkan preseden buruk bagi pelaksanaan aturan tata tertib sekolah selanjutnya.

Secara keseluruhan Tanggung jawab belajar siswa awalnya adalah sedang dengan skor 112,5 atau sekitar 60,8\%. Setelah mengalami pembelajaran dengan Strategi Engaged Learning skor tanggung jawab belajar siswa meningkat menjadi 123,3 atau 66,6\%. Peningkatan tangungjawab belajar ini memberikan keuntungan dalam belajar siswa karena memiliki rasa bertanggung jawab erat kaitannya dengan prestasi di sekolah. Hal ini disebabkan untuk belajar diperlukan tanggung jawab pribadi yang besar sesuai dengan pendapat Harris dkk dalam [9]. Selain itu pengetahuan membutuhkan interaksi konstan antara si belajar dengan lingkungan [10]. 
Hal ini mengisyaratkan bahwa keterlibatan siswa yang berujung pada tanggung jawab belajar akan meningkatkan pemahaman siswa.

Bersesuaian dengan pendapat para ahli tersebut, berdasarkan data hasil post test ternyata kemampuan koneksi matematis mengalami peningkatan rata-rata secara keseluruhan dari $69,4 \%$ menjadi 70,9\%. Peningkatan terjadi pada indikator Mengkoneksikan antar konsep dalam matematika dari $63,4 \%$ menjadi $65,1 \%$ sedangkan untuk indikator Mengkoneksikan antara konsep matematika dengan kehidupan sehari-hari meningkat dari 75,5 menjadi 76,7. Meskipun secara rata-rata skor hasil post-test siswa kelas XIPA2 hanya $1,5 \%$, namun peningkatan ini sudah cukup baik mengingat kompleksnya materi tentang Fungsi Logaritma. Selain itu, pengetahuan awal siswa jauh dari cukup untuk memahami Fungsi Logaritma, terutama pemahaman tentang Fungsi dan pemahaman tentang Logaritma. Namun secara kualitatif, cara siswa menanggapi masalah sudah mulai berubah, dimana tampak keterlibatan disana.

Selain menghasilkan peserta didik yang memiliki tanggung jawab belajar, bersemangat dalam belajar, visi Engaged Learning yang lain adalah pelajar yang strategik, yang terus mengembangkan dan memperbaiki pembelajaran dan strategi pemecahan masalah. Berikut adalah respon siswa ketika ditanya tentang bagaimana mereka memperoleh nilai $\log _{2} 26$ melalui grafik, dimana masalah ini bukan merupakan masalah biasa yang mereka kerjakan dalam pembelajaran.

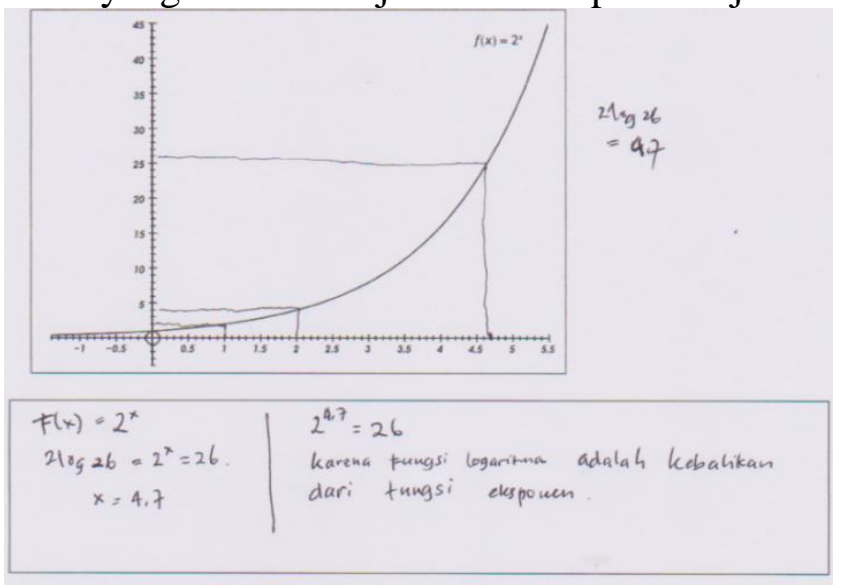

Gambar. 1 Koneksi antara Grafik Fungsi Logaritma dengan Fungsi Eksponen
Walaupun dengan bahasa tulisan yang tidak baku, namun tanggapan siswa ini mengisyaratkan bahwa ia dapat mengkoneksikan bahwa fungsi logaritma merupakan invers dari fungsi eksponen, sehingga melalui grafik eksponen tersebut, ia menentukan $\log _{2} 26$ melalui $\mathrm{f}(\mathrm{y})=\log _{2} \mathrm{y}$.

\section{KESIMPULAN DAN SARAN}

\section{KESIMPULAN}

Secara keseluruhan Tanggung Jawab Belajar siswa mengalami peningkatan sebesar $6 \%$ dimana peningkatan terbesar terjadi pada indikator Berpartisipasi Aktif dalam Pembelajaran. Hal ini terjadi karena masalah nyata yang digunakan dalam pembelajaran sehingga dapat memotivasi siswa untuk menginvestasikan minatnya dalam belajar. Banyak hal menarik yang terjadi selama pembelajaran tentang fungsi logaritma antara lain siswa menemukan bahwa untuk menentukan nilai suatu logaritma kalkulator biasa tidak dapat langsung digunakan, namun harus menggunakan sifat-sifat logaritma terlebih dahulu. Sedangkan untuk kemampuan koneksi matematis mengalami peningkatan skor rata-rata secara keseluruhan sebesar $1,5 \%$. Walaupun sangat kecil, namun peningkatan ini memberikan pengaruh yang baik bagi pembelajaran matematika selanjutnya. Siswa mulai tampak menghubungkan topik yang mereka hadapi dengan kehidupan sehari-hari.

SARAN

Berdasarkan hasil penelitian yang diperoleh dan kelemahan-kelemahan dalam penelitian ini, peneliti memberikan saran sebagai berikut : (1) untuk melibatkan siswa sebaiknya masalah yang diberikan masalah nyata dan menantang, (2) banyak indikator-indikator dalam Engaged Learning merupakan hal baru untuk diterapkan, karena itu perlu direncanakan secara matang oleh guru, agar proses belajar yang menyenangkan dapat terjadi sekaligus materi konten sendiri tidak terabaikan, (3) butuh waktu yang tidak sebentar untuk menumbuh kembangkan sikap dan perilaku Tanggung Jawab Belajar maka dari itu guru harus sabar dan terus menjadi pembimbing dan fasilitator bagi siswa, (4) masalah nyata dan proses diskusi (antar teman, siswa-guru dan diskusi kelas) merupakan unsur utama yang dirasakan penulis 
sangat menunjang keberhasilan pembelajaran, karena itu bagaimana cara mengelola diskusi yang baik perlu dikembangkan lagi untuk mencapai hasil yang lebih baik.

\section{DAFTAR PUSTAKA}

[1] NCTM. 2000. Principles and Standards for School Mathematics. Reston, VA : NCTM

[2] Saepulloh, M. Nur 2014 Perbandingan Peningkatan Kemampuan Berfikir Kreatif Siswa SMP antara Yang Mendapatkan Pembelajaran Dengan Menggunakan Strategi Konflik Kognitif Piaget dan Hasweh. UPI

[3] Triyono, Anjar. 2011. Identifikasi faktor penyebab kesulitan belajar matematika di kelas rendah SD Negeri Karangtengah 1 Kecamatan Sananwetan Kota Blitar. [Online]. Tersedia http://library.um.ac.id/free-contents/index.php/pub/detail/identifikasifaktor-penyebab-kesulitan-belajar-matematika-di-kelas-rendah-sdnegeri-karangtengah-1-kecamatan-sananwetan-kota-blitar-anjartriyono-48376.html [3Mei 2013]

[4] Kartina; Samanhudi; Aisyah dkk. 2011. Active Learning and Student Engagement in Mathematics at Madrasah Ibtidâ'iyah AlJauharotunnaqiyah. UNTIRTA
[5] Hesty. 2007. Implementasi Model Pembelajaran Tematik Untuk Meningkatkan Kemampuan Dasar Siswa Sekolah Dasar. Tesis, Bandung: Universitas Pendidikan Indonesia (tidak diterbitkan)

[6] Schunk, D.H. 1990. Goal Setting and Self-Efficacy During SelfRegulated Learning [Online] Tersedia http://www.tandf.co.uk/journals/ [8 April 2013]

[7] Erickson, D. K. 1999. A Problem-Based Approach to Mathematics Instruction. Connecting Research to Teaching. Vol. 92, No. 6

[8] Taufiq. 2011. Manajemen Kedisiplinan Siswa Sekolah Dasar Studi Multi Kasus pada Sekolah yang Menerapkan Model Sistem Half Day School, Full Day School dan Boarding School [Online] Tersedia : http://www.karya-ilmiah.um.ac.id/ [3 Juni 2015]

[9] Astuti, CP. Pengaruh Bimbingan Belajar Orang Tua Terhadap Tanggung Jawab Belajar Anak Kelas IV SD Pangudi Luhur Don Bosco Semarang Tahun Pelajaran 2003/2004. Semarang: Universitas Negeri Semarang.

[10] Hersovics, N. 1989. Cognitive Obstacles Encountered in the Learning of Algebra. In S.Wagner \& C. Kueran (Eds.), Research issues in the learning and teaching of algebra. Hillscale: Lawrence Erlbaum. 